\title{
Effect of crotamine, a cell-penetrating peptide, on blastocyst production and gene expression of in vitro fertilized bovine embryos
}

\author{
Iana S. Campelo ${ }^{2}$ Alexsandra F. Pereira ${ }^{2}$, Agostinho S. Alcântara-Neto ${ }^{2}$, Natalia G. Canel $^{3}$, \\ Joanna M.G. Souza-Fabjan², Dárcio I.A. Teixeira², Luiz S.A. Camargo ${ }^{4}$, Luciana M. Melo², \\ Gandhi Rádis-Baptista ${ }^{5}$,Daniel F. Salamone ${ }^{3}$ and Vicente J.F. Freitas ${ }^{1}$ \\ Faculty of Veterinary, State University of Ceará, Fortaleza-CE, Brazil; Laboratory of Animal Biotechnology, University of \\ Buenos Aires, Buenos Aires, Argentina; Embrapa Dairy Cattle, Juiz de Fora-MG, Brazil; and Institute of Marine Science, \\ Federal University of Ceará, Fortaleza-CE, Brazil
}

Date submitted: 28.03.2014. Date revised: 16.10.2014. Date accepted: 31.10.2014

\section{Summary}

The present study investigated the effects of crotamine, a cell-penetrating peptide from rattlesnake venom, at different exposure times and concentrations, on both developmental competence and gene expression (ATP1A1, AQP3, GLUT1 and GLUT3) of in vitro fertilized (IVF) bovine embryos. In Experiment 1, presumptive zygotes were exposed to $0.1 \mu \mathrm{M}$ crotamine for 6,12 or $24 \mathrm{~h}$ and control groups (vehicle and IVF) were included. In Experiment 2, presumptive zygotes were exposed to 0 (vehicle), $0.1,1$ and $10 \mu \mathrm{M}$ crotamine for $24 \mathrm{~h}$. Additionally, to visualize crotamine uptake, embryos were exposed to rhodamine B-labelled crotamine and subjected to confocal microscopy. In Experiment 1, no difference $(P>0.05)$ was observed among different exposure times and control groups for cleavage and blastocyst rates and total cells number per blastocyst. Within each exposure time, mRNA levels were similar $(P>0.05)$ in embryos cultured with or without crotamine. In Experiment 2, concentrations as high as $10 \mu \mathrm{M}$ crotamine did not affect $(P>0.05)$ the blastocyst rate. Crotamine at 0.1 and $10 \mu \mathrm{M}$ did not alter mRNA levels when compared with the control $(P>0.05)$. Remarkably, only $1 \mu \mathrm{M}$ crotamine decreased both $A T P 1 A 1$ and $A Q P 3$ expression levels relative to the control group $(P<0.05)$. Also, it was possible to visualize the intracellular localization of crotamine. These results indicate that crotamine can translocate intact IVF bovine embryos and its application in the culture medium is possible at concentrations from $0.1-10 \mu \mathrm{M}$ for 6-24 h.

Keywords: Cattle, Embryotoxicity, Developmental competence, Preimplantation embryo, qPCR

\footnotetext{
${ }^{1}$ All correspondence to: Vicente José de Figueirêdo Freitas. Universidade Estadual do Ceará/Faculdade de Veterinária; Av. Dr. Silas Munguba, 1700-Fortaleza-CE, 60714-903 Brazil. Tel: +55 85 31019861. Fax: +55 85 31019840. e-mail: vicente.freitas@uece.br

${ }^{2}$ Laboratory of Physiology and Control of Reproduction, Faculty of Veterinary, State University of Ceará, FortalezaCE, Brazil.

${ }^{3}$ Laboratory of Animal Biotechnology, University of Buenos Aires, Buenos Aires, Argentina.

${ }^{4}$ Embrapa Dairy Cattle, Juiz de Fora-MG, Brazil.

${ }^{5}$ Laboratory of Biochemistry and Biotechnology, Institute of Marine Science, Federal University of Ceará, Fortaleza-CE, Brazil.
}

\section{Introduction}

The discovery of the genetic code about 50 years ago suggested that gene isolation and transfer into living organisms would become major tools for biologists. The first gene transfer into the mouse revealed the possibility of creating animals that could stably harbour foreign DNA and that had modified phenotypic properties (Gordon et al., 1980; Palmiter et al., 1982).

Pronuclear DNA injection was also used to produce the first transgenic farm animal (Hammer et al., 1985). Despite the inherent inefficiency of microinjection technology, several genetically modified large animals 
have been generated for applications in livestock and biomedicine (Houdebine, 2007).

Several alternatives to pronuclear DNA injection have been developed to improve the efficiency and to reduce the cost of generating transgenic livestock (reviewed in Kues \& Niemann, 2011). To date, somatic cell nuclear transfer (SCNT) holds the greatest promise for significant improvements in the generation of transgenic cattle. However, this method also has proved to be too costly and inefficient for everyday use (Rideout et al., 2001).

For further improvement of transgenic technology in large animals, it is necessary to develop simple, inexpensive and efficient methods. Thus, the use of cell-penetrating peptides (CPPs) constitutes a promising alternative. CPPs are molecules that display the ability to internalize into eukaryotic cells through an energy-independent mechanism and to efficiently carry biologically active and therapeutically relevant molecules inside the cell (Schwarze \& Dowdy, 2000). CPPs are represented by multiple sequences of short and positively charged peptides, rich in arginine and lysine residues, that penetrate through usually impermeable cellular membranes and accumulate in the cytoplasm and/or in the nucleus of the cell (Gupta et al., 2005).

Kerkis et al. (2004) described that crotamine, a myotoxin isolated from the venom of South American rattlesnake (Crotalus durissus terrificus), is a CPP presenting both cytoplasmic and nuclear localization. It was also demonstrated that this toxin is capable of binding electrostatically to plasmid DNA to form a peptide-DNA complex and cargo delivery into cells (Nascimento et al., 2007). Moreover, crotamine in the micromolar range penetrates cells during the $G_{1} / S$ period, binding to centrosomes and chromosomes. Interestingly, in vitro, the exposure of murine stem cells and embryonic fibroblasts to crotamine concentrations between 10 and $0.01 \mu \mathrm{M}$ exhibited no toxicity even after 72 h (Kerkis et al., 2004). Furthermore, CHO-K1 and mice melanoma B16F10 cells exposed to crotamine showed no cytotoxic effect for concentrations up to 1 $\mu \mathrm{M}$ for $24 \mathrm{~h}$ (Hayashi et al., 2008; Nascimento et al., 2012). Even though a few studies have assessed the effects of crotamine on some cell types, only one has described that $\mu \mathrm{M}$ crotamine is able to penetrate intact mouse embryos with no toxicity (Kerkis et al., 2004). In the consulted literature, no studies have been conducted to evaluate the effects of crotamine on cattle preimplantation embryo. Therefore, the aim of this study was to investigate the effects of crotamine, using different exposure times and concentrations, on the quality of in vitro fertilized (IVF) bovine embryos to assess developmental competence and gene expression.

\section{Materials and methods}

Unless indicated otherwise, all chemicals were obtained from Sigma Chemical (St. Louis, MO, USA). This study was approved by the Ethics Committee for Animal Use of the State University of Ceará (No. 12641799-7) and is in accordance with ethical principles of animal experimentation adopted by this committee.

\section{Obtention of crotamine and labelling with rhodamine $B$}

Crotamine was purified previously from the crude venom of rattlesnakes kept in the serpentarium of São Paulo University (Ribeirão Preto, Brazil). The method for crotamine isolation was described previously by Kerkis et al. (2004). Briefly, the venom was diluted with ammonium formate buffer and the bulk of crotoxin, the major venom component, was eliminated by slow-speed centrifugation. Tris-base was added and the solution was applied to a CM-Sepharose FF column $(1.5 \times 4.5 \mathrm{~cm}$; Amersham-Biosciences, Buckinghamshire, UK). Afterwards, the column was washed and crotamine was recovered, dialyzed, lyophilized, and stored at room temperature until use. Before using at embryo culture medium, lyophilized crotamine was dissolved in $150 \mathrm{mM} \mathrm{NaCl}$ solution (vehicle solution).

Preparation and labelling of crotamine with the fluorescent dye rhodamine- $\mathrm{B}(\mathrm{RhB})$ at the $\mathrm{N}$-terminus was achieved as described previously (Rádis-Baptista et al., 2008; Rodrigues et al., 2012). Dried RhB-labelled crotamine was maintained at $-20^{\circ} \mathrm{C}$ until use.

\section{Experimental design}

Two experiments were conducted to evaluate the development and gene expression in bovine embryos exposed to crotamine. In Experiment 1, different exposure times $(6,12$ and $24 \mathrm{~h})$ of $0.1 \mu \mathrm{M}$ crotamine were tested on in vitro culture of IVF presumptive zygotes, with vehicle $(0 \mu \mathrm{M}$ crotamine for each exposure time) and IVF as control groups. The concentration was chosen in accordance with previous studies with human and mouse somatic cells (Kerkis et al., 2004). In Experiment 2, the exposure of IVF presumptive zygotes to different concentrations of crotamine $(0.1,1$ and $10 \mu \mathrm{M})$ for $24 \mathrm{~h}$ was evaluated, using vehicle $(0 \mu \mathrm{M}$ crotamine $=150 \mathrm{mM} \mathrm{NaCl})$ as a control group.

For both experiments, presumptive zygotes were exposed to crotamine or vehicle solutions in $100 \mu \mathrm{l}$ final volume drops composed of $10 \mu \mathrm{l}$ of solution and $90 \mu 1$ of modified CR2aa medium supplemented with $1 \mathrm{mg} / \mathrm{ml}$ fatty acid-free bovine serum albumin 
(BSA) and $2.5 \%$ fetal calf serum (FCS) under mineral oil at $38.5^{\circ} \mathrm{C}$ and atmosphere of $5 \% \mathrm{CO}_{2}$ in air. In Experiment 1, IVF control zygotes were not subjected to such conditions.

\section{Oocyte collection and in vitro maturation (IVM)}

The ovaries of adult cows were collected from a local slaughterhouse and were transported to the laboratory in $0.9 \%(\mathrm{w} / \mathrm{v}) \mathrm{NaCl}$ solution containing antibiotics (Pentabiótico; Fort Dodge, Campinas, Brazil). Cumulus-oocyte complexes (COCs) from follicles of 2-8 $\mathrm{mm}$ in diameter were aspirated using a 21gauge needle attached to a disposable syringe. Only COCs of equal size with evenly granulated ooplasm surrounded by multiple layers of compact cumulus cells were selected in all experiments. After collection, the COCs were washed four times with HEPESTyrode's lactate-pyruvate-albumin (TALP-H). Groups of up to 50 COCs were placed in $500 \mu \mathrm{l}$ of maturation medium containing bicarbonate-buffered medium 199 supplemented with 10\% (v/v) FCS (Gibco, Carlsbad, CA, USA), $0.2 \mathrm{mM}$ sodium pyruvate, $50 \mu \mathrm{g} / \mathrm{ml}$ gentamycin, $10 \mathrm{ng} / \mathrm{ml}$ epidermal growth factor (EGF), $100 \mu \mathrm{M}$ cysteamine, $20 \mu \mathrm{g} / \mathrm{ml}$ follicle-stimulating hormone/leuteinizing hormone (FSH/LH; Pluset; Calier, Barcelona, Spain) and $1 \mu \mathrm{g} / \mathrm{ml} 17 \beta$-estradiol. IVM was performed at $38.5^{\circ} \mathrm{C}$ for $24 \mathrm{~h}$ in a humidified atmosphere of $5 \% \mathrm{CO}_{2}$ in air.

\section{In vitro fertilization (IVF)}

Matured COCs were placed in Petri dishes that contained $100 \mu \mathrm{l}$ of Fert-TALP medium supplemented with $20 \mu \mathrm{g} / \mathrm{ml}$ heparin (Hemofol; Cristália, Itapira, Brazil) and $6 \mathrm{mg} / \mathrm{ml}$ fatty acid-free BSA. IVF was performed with frozen-thawed Percoll-separated semen (final concentration of $15 \times 10^{6}$ spermatozoa $/ \mathrm{ml}$ ) covered with mineral oil (Irvine Scientific, Santa Ana, CA, USA) at $38.5^{\circ} \mathrm{C}$ under an atmosphere of $5 \%$ $\mathrm{CO}_{2}$ in air with maximum humidity. Approximately $6 \mathrm{~h}$ post insemination (hpi), presumptive zygotes were denuded by repeated pipetting in TALP-H for immediate exposure with crotamine for different times and concentrations.

\section{In vitro embryo development}

After exposure to crotamine, embryos were cultured in $50 \mu$ droplets of modified CR2aa medium supplemented with $1 \mathrm{mg} / \mathrm{ml} \mathrm{BSA}$ and $10 \%$ FCS under mineral oil at $5 \% \mathrm{CO}_{2}$ in air and $38.5^{\circ} \mathrm{C}$ in high humidity for 192 hpi. Cleavage was assessed at 72 hpi and blastocyst at 168 (day 7) and 192 (day 8) hpi. At day 8 of culture, embryos were stained in Hoechst 33342 (Pursel et al., 1985) and mounted between coverslips to count the total nuclei number under an epifluorescence microscope (Eclipse E400; Nikon, Tokyo, Japan).

\section{Translocation assay}

For assessment of crotamine translocation into presumptive zygotes, embryos were exposed to $10 \mu \mathrm{M}$ RhB-labelled crotamine or vehicle solution $(\mathrm{NaCl} 150$ $\mathrm{mM}$ ) for $6 \mathrm{~h}$ post IVF in $50-\mu \mathrm{l}$ final volume droplets composed of $5 \mu \mathrm{l}$ of solution and $45 \mu \mathrm{l}$ of synthetic oviductal fluid (SOF) (Tervit et al., 1972) modified by Holm et al. (1999) under mineral oil at $38.5^{\circ} \mathrm{C}$ and atmosphere of $5 \% \mathrm{CO}_{2}$ in air. After exposure, zygotes were washed in TALP-H and the zona pellucida (ZP) was removed by treatment with $1.5 \mathrm{mg} / \mathrm{ml}$ pronase (P8811). Afterward, embryos were fixed in $4 \%$ (v/v) paraformaldehyde (F1635) for $20 \mathrm{~min}$ and washed for $30 \mathrm{~min}$ in PBS supplemented with $0.4 \%$ $(\mathrm{w} / \mathrm{v})$ BSA and $1 \%(\mathrm{v} / \mathrm{v})$ antibiotic-antimycotic (ATBATM, 15240-096; Gibco BRL). Samples were stored in supplemented PBS at $4^{\circ} \mathrm{C}$ until use. Nuclear DNA was counterstained with $0.2 \mathrm{mg} / \mathrm{ml}$ of DAPI (D9542) for $10 \mathrm{~min}$ in the dark, and washed in supplemented PBS for $5 \mathrm{~min}$. Stained embryos were mounted between coverslips in $70 \%(\mathrm{v} / \mathrm{v})$ glycerol and stored at $20^{\circ} \mathrm{C}$. Crotamine uptake by embryos was detected by confocal microscopy on a Zeiss LSM 510 Meta Confocal microscope (Zeiss, Germany). DAPI and RhB fluorescence was detected with excitation wavelengths of 405 and $543 \mathrm{~nm}$, respectively. Complete Z series of 12 optical sections at 4-5 $\mu \mathrm{m}$ intervals were acquired from each embryo and three-dimensional images were constructed using the LSM Image Browser software (Zeiss, Germany).

\section{RNA extraction and reverse transcription (RT)}

Total RNA was prepared from three pooled hatched blastocysts (day 8 of culture) in quadruplicates as group samples using the RNeasy micro kit (Qiagen Sci.; Germantown, MD, USA) following the manufacturer's instructions. Briefly, $75 \mu \mathrm{l}$ lysis buffer was added to each frozen sample and the lysate was diluted 1:1 with 70\% ethanol and transferred to a spin column. Genomic DNA was degraded using RNasefree DNase for $15 \mathrm{~min}$ at room temperature. After three washes, the RNA was eluted with $10 \mu l$ RNasefree water. The RT step was performed with $1 \mu \mathrm{l}$ of Improm II (Promega; Madison, WI, USA) in buffer, combined with $0.5 \mathrm{mM}$ of each dNTP (Promega), $40 \mathrm{U}$ of RNasin (Promega), and RNase-free water to make a final reaction volume of $20 \mu \mathrm{l}$. RT was achieved at $42^{\circ} \mathrm{C}$ for $60 \mathrm{~min}$, followed by $70^{\circ} \mathrm{C}$ for $15 \mathrm{~min}$. First-strand cDNA products were then stored at $-80^{\circ} \mathrm{C}$ for later use as template for further gene expression analysis. Negative controls or RT blanks were prepared under 
Table 1 Oligonucleotides used for qPCR analysis of gene expression in in vitro fertilized bovine embryos

\begin{tabular}{lllc}
\hline Gene & \multicolumn{1}{c}{ Primer sequence $\left(5^{\prime} \rightarrow 3^{\prime}\right)$} & $\begin{array}{c}\text { GenBank accession } \\
\text { number }\end{array}$ & $\begin{array}{c}\text { Product } \\
\text { size }(\mathrm{bp})\end{array}$ \\
\hline ATP1A1 & F: AACCGGCAGCTGTTTCAGAG; R:TAAGCCTCGGCTCAAGTCTG & NM_001076798 & 152 \\
AQP3 & F: TGAACCCTGCCGTGACATTT; R:GGCCCAGATCGCATCGTAAT & NM_001079794 & 143 \\
GLUT1 & F: CACTGGAGTCATCAACGCCC; R:CGGCCGAAACGGTTAACAAA & M60448 & 189 \\
GLUT3 & F: CATCAATGCTCCTGAGGCGA; R:AGCCAATCATACCACCCACG & NM_174603 & 143 \\
GAPDH & F: TTCAACGGCACAGTCAAGG; R:ACATACTCAGCACCAGCATCAC & NM_001034034 & 119 \\
H2A & F: TCCGGAAAGGCCAAGACAAA; R: GTGTCGATGAATACGGCCCA & NM174809 & 81 \\
\hline
\end{tabular}

$\mathrm{F}$, forward primer; $\mathrm{R}$, reverse primer.

the same conditions, but with no inclusion of reverse transcriptase.

\section{Quantitative real-time PCR}

Quantitative real-time polymerase chain reaction (qPCR) amplifications were performed in a MasterCycler EP Realplex4 S (Eppendorf AG; Hamburg, Germany). The quadruplicates of cDNA from each group were pooled prior to PCR experiments. Thereafter, the pooled cDNA were run in triplicate for target and reference genes (Table 1). Target genes were $\mathrm{Na} / \mathrm{K}$ ATPase isoform 1 (ATP1A1), aquaporin 3 (AQP3), glucose transporter-1 (GLUT1) and glucose transporter-3 (GLUT3). These genes were chosen to evaluate osmotic regulation, blastocoele formation and energy metabolism of the embryos. Reference genes were glyceraldehyde 3-phosphate dehydrogenase $(G A P D H)$ and member $\mathrm{Z}$ of the $\mathrm{H} 2 \mathrm{~A}$ histone family $(H 2 A)$. Each reaction consisted of 20 $\mu l$ total volume containing $10 \mu \mathrm{l} 2 \times$ Power SYBR Green PCR Master Mix (Applied Biosystems; Foster City, CA, USA), $0.3 \mu \mathrm{M}$ of each primer and 0.5 $\mu l$ cDNA (equivalent to 0.075 embryo). The qPCR protocol consisted of an initial incubation at $95^{\circ} \mathrm{C}$ for $10 \mathrm{~min}$, followed by 40 cycles of an amplification program of $95^{\circ} \mathrm{C}$ for $15 \mathrm{~s}, 55^{\circ} \mathrm{C}$ for $15 \mathrm{~s}$ and $60^{\circ} \mathrm{C}$ for $30 \mathrm{~s}$. Fluorescence data were acquired during the $72{ }^{\circ} \mathrm{C}$ extension step. Threshold, quantification cycle $(\mathrm{Cq})$, and melting temperature (Tm) values were automatically determined by Realplex 2.2 software (Eppendorf AG), using default parameters. To determine the linearity $\left(\mathrm{R}^{2}\right)$ and the efficiency $(\mathrm{E})$ of the PCR amplifications, standard curves were generated for each gene using serial dilutions of a cDNA preparation from 20 (for GAPDH, H2A and ATP1A1) or 40 (for AQP3, GLUT1 and GLUT3) hatched blastocysts, with all other conditions being identical. Specificity of each reaction was achieved by performing the melting procedure $\left(55-95^{\circ} \mathrm{C}\right.$, starting fluorescence acquisition at $55^{\circ} \mathrm{C}$ and taking measurements at $10 \mathrm{~s}$ intervals until the temperature reached $95^{\circ} \mathrm{C}$ ) after every qPCR run. Samples with RNA but with no reverse transcriptase were used as negative controls.

\section{Data analysis}

The statistical analysis of cleavage and blastocyst rates was assessed by the non-parametric Fisher's exact test, whereas the average number of nuclei per blastocyst was compared using one-way analysis of variance (ANOVA). The relative quantification of gene expression was performed using the $2^{-\Delta \Delta C t}$ method (Livak \& Schmittgen, 2001). Target gene expression was normalized against the geometric mean of GAPDH and $H 2 A$ transcript levels (Vandesompele et al., 2002). The differences in relative abundance of specific transcripts were compared using the KruskalWallis test followed by the post-hoc Dunn's test. The corresponding qPCR efficiencies were calculated from the given slopes $(S)$ of the standard curves, according to the equation: $\mathrm{E}=10^{(-1 / \mathrm{S})}-1$. Linearity was expressed as the square of the Pearson correlation coefficient $\left(R^{2}\right)$. Tm data were expressed as mean \pm standard deviation (SD) of three or more measurements. For all analysis, $P$-value $<0.05$ was considered to be statistically significant using Prism 6.0 software (GraphPad Software Inc.; La Jolla, CA, USA).

\section{Results}

\section{Embryo development}

The present study assessed the possible effects of crotamine on the quality of IVF bovine embryos. Thus, we evaluated developmental competence up to the blastocyst stage. In addition, gene expression of selective quality genes from embryos exposed to crotamine in comparison with controls was quantitatively analyzed by qPCR.

In Experiment 1, 2320 presumptive zygotes from 10 replicates produced 1281 (55.2\%) cleaved embryos and $740(31.9 \%)$ blastocysts. Cleavage and blastocyst rates were similar in zygotes exposed to $0.1 \mu \mathrm{M}$ crotamine for 6, 12 or $24 \mathrm{~h}(P>0.05)$ as well as to vehicle (0 $\mu \mathrm{M}$ crotamine) and IVF control groups (Table 2). Thus, exposing zygotes to $0.1 \mu \mathrm{M}$ crotamine in the culture medium, even for as long as $24 \mathrm{~h}$, did not 
Table 2 Effect of exposure time with crotamine at $0.1 \mu \mathrm{M}$ on development of in vitro fertilized bovine embryos

\begin{tabular}{|c|c|c|c|c|c|c|}
\hline \multirow{2}{*}{$\begin{array}{l}\text { Exposure } \\
\text { time (h) }\end{array}$} & \multirow[b]{2}{*}{ Crotamine } & \multirow{2}{*}{$\begin{array}{c}\text { Presumptive } \\
\text { zygotes }\end{array}$} & \multirow{2}{*}{$\begin{array}{c}\text { Cleavage } \\
(\%)\end{array}$} & \multicolumn{2}{|c|}{ Blastocyst (\%) } & \multirow{2}{*}{$\begin{array}{l}\text { Hatching } \\
(\%)^{*}\end{array}$} \\
\hline & & & & Day 7 & Day 8 & \\
\hline \multirow[t]{2}{*}{6} & + & 359 & $193(53.8)^{a}$ & $104(29.0)^{a}$ & $113(31.5)^{a}$ & $54(47.8)^{a}$ \\
\hline & - & 305 & $169(55.4)^{a}$ & $84(27.5)^{a}$ & $98(32.1)^{a}$ & $48(49.0)^{a}$ \\
\hline \multirow[t]{2}{*}{12} & + & 297 & $166(55.9)^{a}$ & $90(30.3)^{a}$ & $101(34.0)^{a}$ & $52(51.5)^{a}$ \\
\hline & - & 296 & $162(54.7)^{a}$ & $79(26.7)^{a}$ & $87(29.4)^{a}$ & $41(47.1)^{a}$ \\
\hline \multirow[t]{2}{*}{24} & + & 409 & $223(54.5)^{a}$ & $115(28.1)^{a}$ & $134(32.8)^{a}$ & $61(45.5)^{a}$ \\
\hline & - & 296 & $165(55.7)^{a}$ & $92(31.1)^{a}$ & $92(31.1)^{a}$ & $49(53.3)^{a}$ \\
\hline IVF control & na & 358 & $203(56.7)^{a}$ & $102(28.5)^{a}$ & $115(32.1)^{a}$ & $59(51.3)^{a}$ \\
\hline
\end{tabular}

Experiment was replicated 10 times. ${ }^{a}$ Values with different superscripts within the same column differ significantly $(P<0.05)$.

${ }^{*}$ Calculated from total number of blastocysts. na, not applicable.

Table 3 Effect of crotamine concentration on development of in vitro fertilized bovine embryos

\begin{tabular}{lccccc}
\hline & & & \multicolumn{2}{c}{ Blastocysts (\%) } & \\
\cline { 4 - 5 } Crotamine $(\mu \mathrm{M})$ & Presumptive zygotes & Cleavage $(\%)$ & Day 7 & Day 8 & Hatching $(\%)^{*}$ \\
\hline 0 & 295 & $168(57.0)^{a}$ & $70(23.7)^{a}$ & $85(28.8)^{a}$ & $37(43.5)^{a}$ \\
0.1 & 296 & $141(47.6)^{b}$ & $69(23.3)^{a}$ & $81(27.4)^{a}$ & $38(46.9)^{a}$ \\
1 & 298 & $154(51.7)^{a, b}$ & $56(18.8)^{a}$ & $69(23.1)^{a}$ & $31(44.9)^{a}$ \\
10 & 309 & $179(57.9)^{a}$ & $65(21.0)^{a}$ & $77(24.9)^{a}$ & $31(40.3)^{a}$ \\
\hline
\end{tabular}

Experiment was replicated 10 times. ${ }^{a, b}$ Values with different superscripts within the same column differ significantly $(P<0.05)$.

*Calculated from total number of blastocysts.

affect cleavage and blastocyst production $(P>0.05)$. Additionally, embryo development appeared to be synchronized, as the blastocyst hatching rates at day 8 were statistically identical $(P>0.05)$ between the groups with or without crotamine for 6, 12 and $24 \mathrm{~h}$ or IVF control (Table 2).

Regarding Experiment 1, the exposure time to 0.1 $\mu \mathrm{M}$ crotamine did not affect the total number of nuclei per blastocyst when compared with the IVF control $(P>0.05)$. Expanded blastocysts had nuclei counts (mean \pm SD) of $127.7 \pm 54.1,130.3 \pm 37.6$ and $132.7 \pm 47.1$ after 6,12 or $24 \mathrm{~h}$ of crotamine exposure time, respectively, and $116.9 \pm 28.9,126.2 \pm 32.7$ and $133.4 \pm 41.8$ after 6,12 or $24 \mathrm{~h}$ of vehicle exposure time, respectively. The IVF control produced expanded blastocysts with $116.3 \pm 44.5$ nuclei per embryo, similar $(P>0.05)$ to all exposure times of crotamine or vehicle solution. Likewise, hatched blastocysts, exposed or not to crotamine, respectively, had similar $(P>0.05)$ nuclei counts for the $6 \mathrm{~h}(175.4 \pm 59.7$ versus $220.8 \pm 65.6)$, $12 \mathrm{~h}(151.0 \pm 37.9$ versus $179.5 \pm 46.4)$ and $24 \mathrm{~h}$ $(203.9 \pm 92.2$ versus $207.8 \pm 71.2)$ treatments. In addition, all these nuclei counts were similar $(P>0.05)$ to that of the IVF control $(210.8 \pm 79.9)$.

Exposure to $150 \mathrm{mM} \mathrm{NaCl}$ up to $24 \mathrm{~h}$ did not affect bovine embryo development, when compared with the IVF control. Therefore, in Experiment 2, the control group was formed by embryos exposed to vehicle solution. In this assay, 1198 presumptive zygotes from 10 replicates produced $642(53.6 \%)$ cleaved embryos and $312(26.0 \%)$ blastocysts. Overall, concentrations as high as $10 \mu \mathrm{M}$ crotamine did not affect the blastocyst rates evaluated at days 7 and 8 (Table 3). In addition, the hatching rates measured at day 8 were similar $(P>0.05)$ among different crotamine concentrations.

\section{Gene expression}

Initially, to validate our qPCR conditions, standard curves prepared with serial dilutions of embryo cDNAs were plotted for all genes. These experiments give valuable information about the range of template concentrations that yielded adequate amplification efficiencies. In our analyses, when using the cDNA from 0.00016 to 1 embryo per reaction (varying according to the gene, Table 4), amplification reactions presented high linearity $\left(R^{2} \geq 0.98\right)$ and efficiency near to 1 (E from 0.99 to 1.05). These results indicate that differentially expressed mRNA species presented in this study can be analyzed using our qPCR conditions, as long as the template concentrations (such as 0.075 embryo per reaction) fall within the linear range (Dussault \& Pouliot, 2006). Thus, qPCR amplifications were specific, once derivative melting curve of 
Table 4 Standard curve parameters for validation of qPCR amplifications in IVF bovine embryos

\begin{tabular}{lccccr}
\hline Gene & Slope & Efficiency & $\mathrm{R}^{2}$ & Template range (number of embryos) $^{a}$ & Tm $\left.^{\circ}{ }^{\circ} \mathrm{C}\right)^{b}$ \\
\hline ATP1A1 & -3.335 & 0.99 & 0.98 & $0.004-0.5$ & $79.55 \pm 0.20$ \\
AQP3 & -3.319 & 1.00 & 0.98 & $0.00032-1$ & $85.39 \pm 0.24$ \\
GLUT1 & -3.302 & 1.01 & 0.99 & $0.00032-1$ & $86.43 \pm 0.24$ \\
GLUT3 & -3.213 & 1.05 & 1.00 & $0.008-1$ & $84.09 \pm 0.27$ \\
GAPDH & -3.276 & 1.02 & 0.98 & $0.00016-0.5$ & $82.68 \pm 0.26$ \\
H2A & -3.283 & 1.02 & 0.98 & $0.0008-0.5$ & $83.87 \pm 0.26$ \\
\hline
\end{tabular}

${ }^{a}$ Standard curves were constructed for target (ATP1A1, AQP3, GLUT1 and GLUT3) and reference (GAPDH and H2A) genes and the successfully amplified template ranges were presented.

${ }^{b}$ Derivative melting curves of target and reference gene amplicons produced the mean Tm values.

amplicons produced a single peak per gene. Finally, no amplification was observed for samples without reverse transcriptase enzyme (negative controls) in reaction tube.

In general, ATP1A1, AQP3, GLUT1 and GLUT3 transcripts were detected successfully in all bovine embryos regardless of the exposure to crotamine. In Experiment 1, the presence of $0.1 \mu \mathrm{M}$ crotamine in the culture medium did not affect gene expression of bovine embryo even up to $24 \mathrm{~h}$ (Fig. 1). Within each exposure time, mRNA levels were similar $(P>0.05)$ in embryos exposed or not to crotamine. Also, expression in each crotamine group did not differ $(P>0.05)$ from the IVF control. As expected, exposure up to $24 \mathrm{~h}$ with only vehicle solution did not alter $(P>0.05)$ the levels of ATP1A1, AQP3, GLUT1 or GLUT3 transcripts in bovine embryos when compared with IVF group. In Experiment 2 (Fig. 2), 0.1 and 10 $\mu \mathrm{M}$ crotamine concentrations for $24 \mathrm{~h}$ did not induce mRNA level changes when compared with the vehicle control. Remarkably, only at the concentration of 1 $\mu \mathrm{M}$, crotamine decreased both ATP1A1 and AQP3 expression relative to vehicle control, whereas GLUT1 and GLUT3 transcript levels were similar $(P>0.05)$.

\section{Crotamine translocation}

It was possible to visualize crotamine translocation through ZP of IVF bovine zygotes as soon as after $6 \mathrm{~h}$ exposure (Fig. 3). Moreover, partial overlapping of crotamine signal and DAPI nuclear DNA staining was observed. ZP removal after exposure and prior to fixation allowed us to differentiate membrane and intracellular labelling of embryos instead of possible ZP labelling.

\section{Discussion}

In the present work, the effect of crotamine on the in vitro development of bovine embryos and the quantitative expression of selected embryo quality genes were investigated. Immediately after fertil- ization, presumptive zygotes were cultured in the presence of $0.1-10 \mu \mathrm{M}$ crotamine and for up to $24 \mathrm{~h}$ exposure. Overall, crotamine did not impair or disturb the embryo development under assayed conditions.

The presence of $0.1 \mu \mathrm{M}$ crotamine in the culture medium even for $24 \mathrm{~h}$ neither affected the embryo production, as indicated by similar blastocyst rates among crotamine and control groups, nor morphological embryo quality, inferred by total nuclei counting. These data suggest that, under those conditions, crotamine has no negative effect on preimplantation development. It is possible that future applications of crotamine as CPP for animal transgenesis by embryo transfection may be limited to an exposure time of not longer than $24 \mathrm{~h}$ once the crotamine uptake by embryo seems to occur before $6 \mathrm{~h}$ of incubation. Kerkis et al. (2004) investigated in vitro the Cy3-crotamine uptake at $1 \mu \mathrm{M}$ by human primary fibroblasts, lymphoblastic cells, murine embryonic stem and endothelial s-vec cells, monitoring the crotamine uptake after $5 \mathrm{~min}$ and $1,3,24$, or 48 h of treatment by confocal microscopy. As indicated by this study, the cells internalized crotamine as fast as $5 \mathrm{~min}$ after its addition and the number of labelled cells reached a maximum after about $3 \mathrm{~h}$ of treatment. A similar interval for cellular uptake of fluorescently labelled crotamine was reported for highly proliferative CHO-K1 cells (Hayashi et al., 2008). Conversely, when considering embryos, it is important to highlight that the barrier imposed by ZP could delay this time of internalization. However, crotamine uptake at $1 \mu \mathrm{M}$ concentration was evidenced in compact mouse morulae after $24 \mathrm{~h}$ exposure (Kerkis et al., 2004), indicating that this time was enough for crotamine to reach the inner cell mass of murine intact blastocysts.

The ZP is a glycoproteinaceous translucent matrix that surrounds the mammalian oocyte and plays a critical role in achieving fertilization (Gupta et al., 2012). Another relevant aspect is the ZP glycoproteic composition, as crotamine-carbohydrate interaction plays a fundamental role in the first step of cell internalization, as reported extensively (reviewed in Rádis-Baptista \& Kerkis, 2011). In fact, it is known 

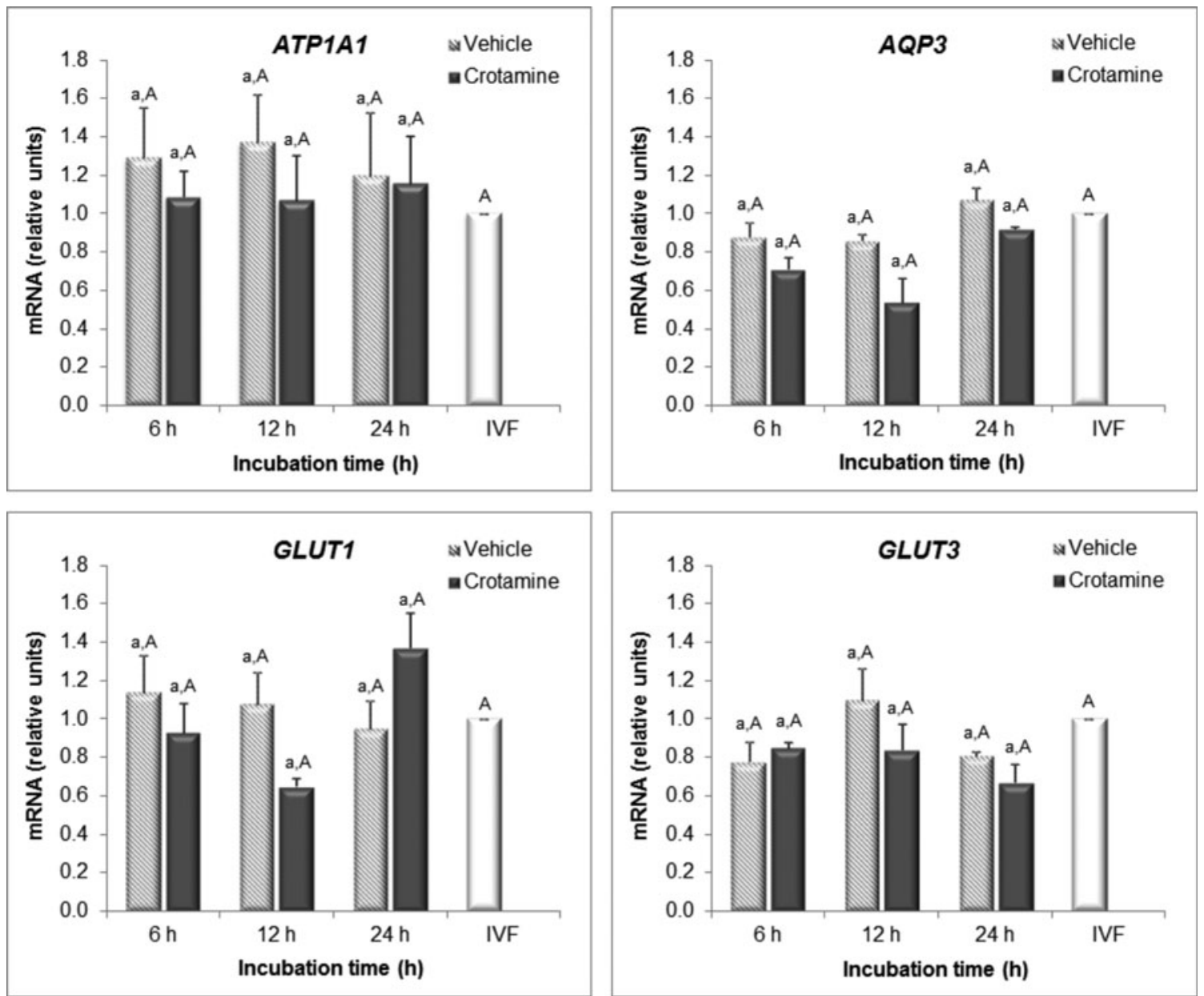

Figure 1 Effect of crotamine exposure time on gene expression of in vitro fertilized bovine embryos. Quantification of ATP1A1, $A Q P 3$, GLUT1 and GLUT3 transcripts was performed by qPCR using GAPDH and $H 2 A$ as reference genes. The IVF group was used as calibrator. Comparisons were made between groups within each exposure time $(\mathrm{a}, \mathrm{b}: P<0.05)$ or for each group versus IVF (A, B: $P<0.05)$.

that some CPPs interact electrostatically with the extracellular matrix of the cell followed by endocytosis (Richard et al., 2003; Nascimento et al., 2007). More specifically, crotamine internalization seems to be mediated by heparan sulphate proteoglycans (HSPGs) in the uptake phase (Nascimento et al., 2007). In the context of the present study, we did not confirm if $\mathrm{N}$ - and $\mathrm{O}$-glycans of bovine embryo ZP could interact with crotamine in the culture medium. Therefore, it is premature to infer whether the $\mathrm{ZP}$ itself could affect the number of crotamine molecules available for embryo cell uptake.

After $0.1 \mu \mathrm{M}$, we used 1 or $10 \mu \mathrm{M}$ crotamine in the culture medium also for $24 \mathrm{~h}$ exposure with presumptive zygotes. The presence of crotamine concentrations greater than $0.1 \mu \mathrm{M}$ seems to not affect the final production and quality of 8-day embryos. Nonetheless, levels of ATP1A1 and AQP3 transcripts detected in embryos exposed for $24 \mathrm{~h}$ to $1 \mu \mathrm{M}$ crotamine were lower than in the control, but similar to $10 \mu \mathrm{M}$ crotamine treatment. Interestingly, levels of $A T P 1 A 1$ and $A Q P 3$ transcripts in embryos exposed to $0.1 \mu \mathrm{M}$ and $10 \mu \mathrm{M}$ crotamine for $24 \mathrm{~h}$ were similar to that of the control. Indeed, alterations in mRNA levels in 8-day embryos were not detected for GLUT1 and GLUT3 in any crotamine group. Additionally, in Experiment 1, embryos subjected to all exposure times with $0.1 \mu \mathrm{M}$ crotamine had the same relative levels of all transcripts (ATP1A1, AQP3, GLUT1 and GLUT3) as the control groups. The expression level of these genes has been correlated with embryo quality (Camargo et al., 2011; Kuzmany et al., 2011) as the encoded proteins play important roles in the physiological process at preimplantation stage of embryo development (Rizos et al., 2008). The expression of ATP1A1 and AQP3 genes is reported to be involved in embryo osmotic regulation and blastocoele formation. ATP1A1 is the protein of the $\mathrm{Na} / \mathrm{K}$ ATPase subunit responsible for generating an ionic gradient through the trophectoderm and subsequent 

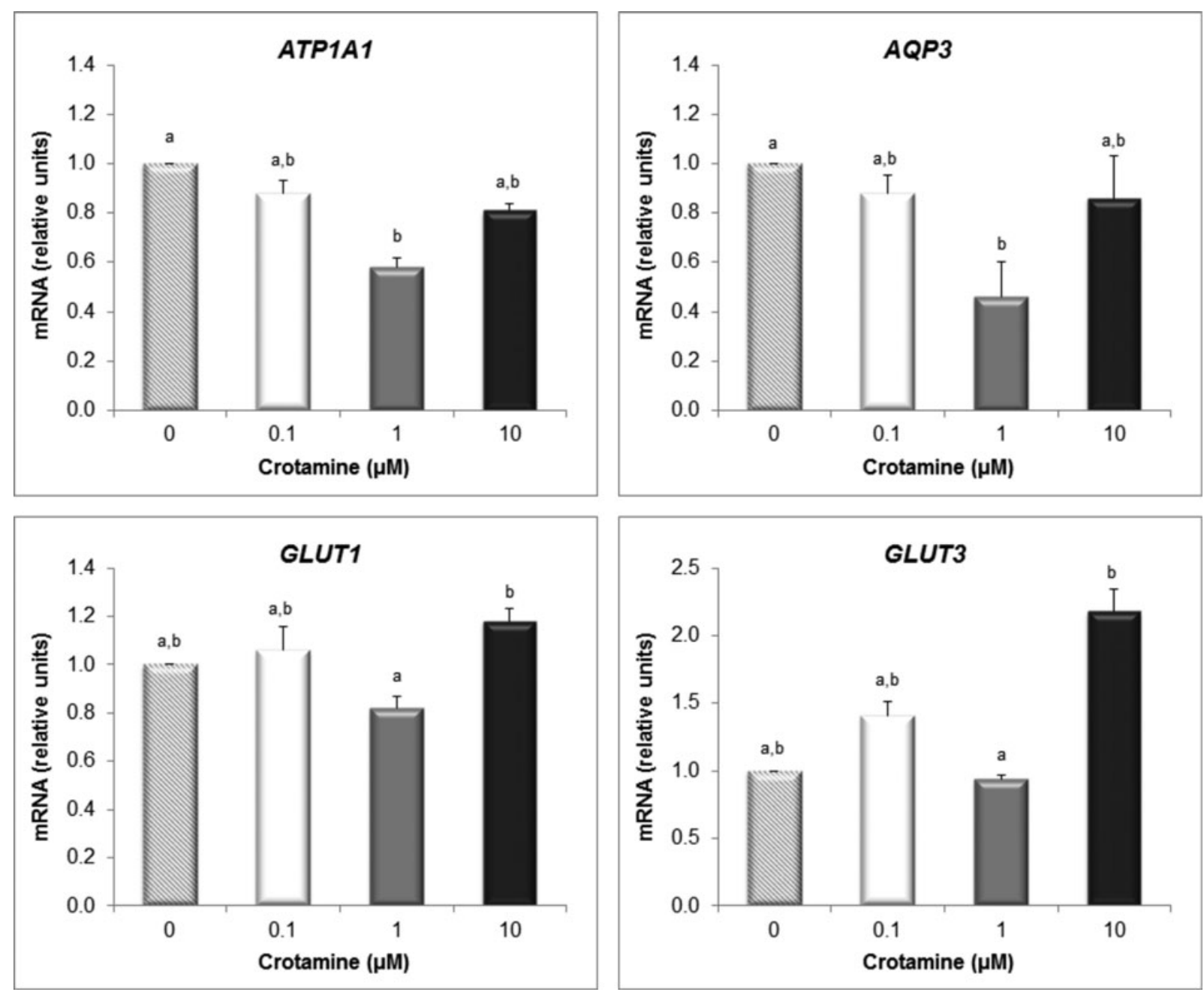

Figure 2 Effect of crotamine concentration on gene expression of in vitro fertilized embryos. Quantification of $A T P 1 A 1, A Q P 3$, GLUT1 and GLUT3 transcripts were performed by qPCR using GAPDH and $H 2 A$ as reference genes. The vehicle group $(0 \mu \mathrm{M}$ crotamine) was used as calibrator. Bars with different superscripts $(\mathrm{a}, \mathrm{b})$ are significantly different at $P<0.05$.

water influx to the blastocoele (Watson et al., 1999). $A Q P 3$ is an aquaglyceroporin that increases cellular permeability to water and other small solutes, such as glycerol, urea, purines and pyrimidines (Barcroft et al., 2003). The GLUT proteins are described as being engaged in the energy metabolism of the mammalian embryos (Purcell \& Moley, 2009). GLUT3 has been reported to play a central role in glucose absorption, while GLUT1 is responsible for intracellular glucose transport (Augustin et al., 2001).

In this context, the similarity of expression of GLUT1 and GLUT3 genes between embryos exposed to crotamine or vehicle solutions suggests that energy metabolism concerned with glucose uptake is not disturbed. Only embryos cultured in the presence of $1 \mu \mathrm{M}$ crotamine for $24 \mathrm{~h}$ decreased the expression of osmotic-related genes (ATP1A1 and AQP3), while concentrations lower and higher than $1 \mu \mathrm{M}$ did not affect these levels. It is possible that the $0.1 \mu \mathrm{M}$ concentration is not able to alter the osmotic response of bovine embryos, whereas a crotamine concentration of $10 \mu \mathrm{M}$ could promote a start-up compensatory embryo response at transcriptional level faster than that of $1 \mu \mathrm{M}$ crotamine. This pattern of gene expression regulation on in vitro cultured bovine embryos has been reported previously in response to the presence of some substances in the culture medium (Camargo et al., 2011). Nevertheless, these changes did not interfere with in vitro development of bovine embryos, as both blastocyst and hatching rates were similar among all groups.

In conclusion, crotamine application as a cellpenetrating peptide for bovine transgenesis and embryo transfection is apparently viable from the standpoint of its inherent capacity of translocate into intact IVF embryos and due to the lack of detectable toxicity. Moreover, as demonstrated in the current study, it is possible to use crotamine in the culture 

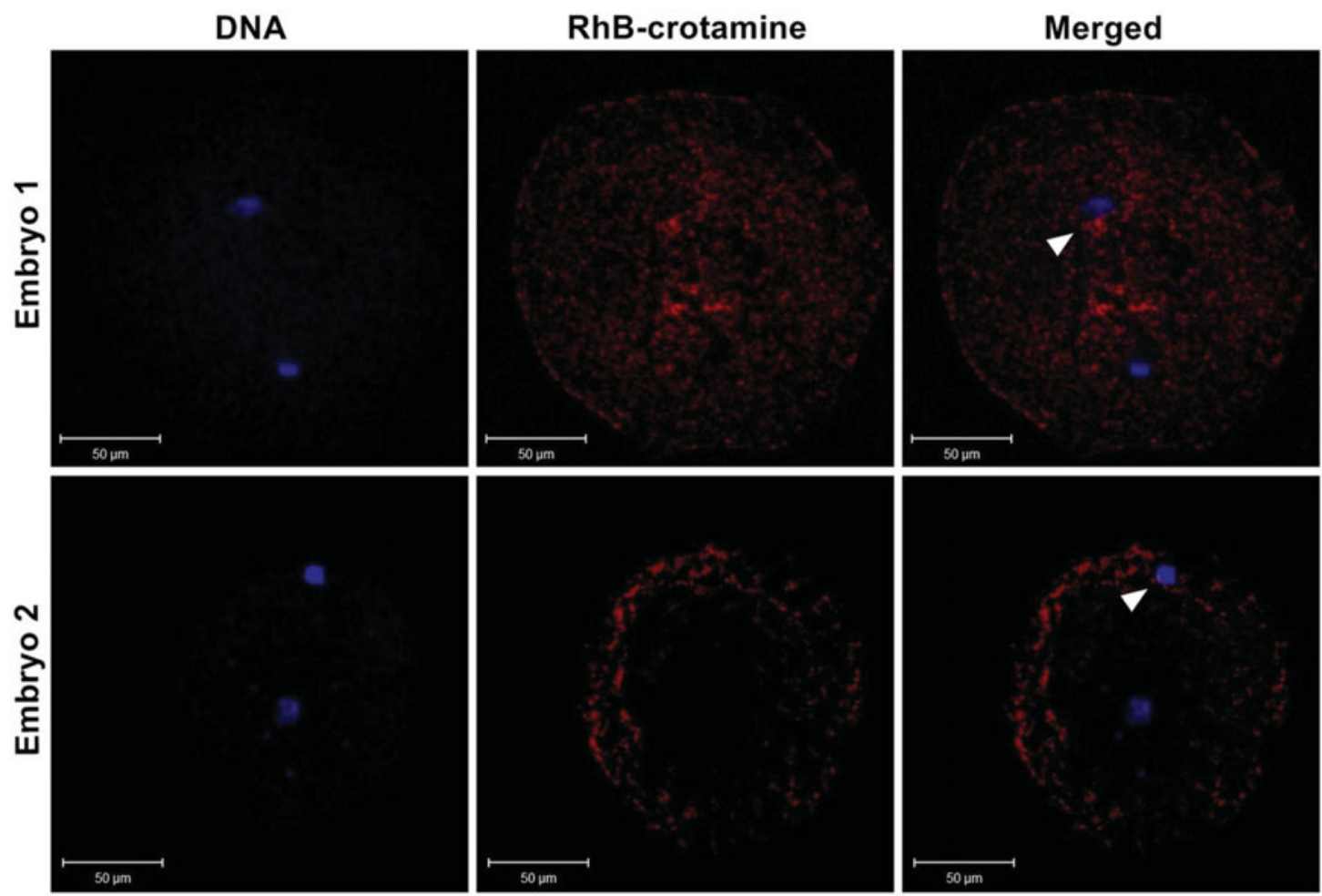

Figure 3 Crotamine uptake by IVF bovine embryos after $6 \mathrm{~h}$ exposure to $10 \mu \mathrm{M}$ RhB-labelled crotamine. Crotamine labelling (red) and nuclei counterstaining with DAPI (blue) was observed into fixed bovine zygote by fluorescence confocal microscopy. Partial overlapping of crotamine and DAPI fluorescence was seen (arrowhead).

medium with concentrations ranging from $0.1-10 \mu \mathrm{M}$ and exposure time from 6-24 h. Further studies could address the feasibility of crotamine as an effective carrier of DNA molecules into intact bovine embryos.

\section{Financial support}

This study was supported by CNPq (grant number 560613/2010-5). I.S.C. was supported by an MSc scholarship from FUNCAP. A.F.P., J.M.G.S-F and L.M.M. were supported by postdoctoral fellowships from $\mathrm{CNPq}$ and CAPES, respectively.

\section{Conflict of interest}

There are no conflicts of interest.

\section{Acknowledgements}

The authors would like to acknowledge Prof. Eduardo Brandt de Oliveira (University of São Paulo, Ribeirão Preto, Brazil) for providing crotamine. We are also thankful to Mr Claudio Andrade (inspection service of slaughterhouse, Morada Nova, Brazil) for supplying bovine ovaries.

\section{References}

Augustin, R., Pocar, P., Navarrete-Santos, A., Wrenzycki, C., Gandolfi, F., Niemann, H. \& Fischer, B. (2001). Glucose transporter expression is developmentally regulated in in vitro derived bovine preimplantation embryos. Mol. Reprod. Dev. 60, 370-6.

Barcroft, L.C., Offenberg, H., Thomsen, P. \& Watson, A.J. (2003). Aquaporin proteins in murine trophectoderm mediate transepithelial water movements during cavitation. Dev. Biol. 256, 342-54.

Camargo, L.S., Boite, M.C., Wohlres-Viana, S., Mota, G.B., Serapião, R.V., Sa, W.F., Viana, J.H. \& Nogueira, L.A. (2011). Osmotic challenge and expression of aquaporin 3 and $\mathrm{Na} / \mathrm{K}$ ATPase genes in bovine embryos produced in vitro. Cryobiology 63, 256-62.

Dussault, A.A. \& Pouliot, M. (2006). Rapid and simple comparison of messenger RNA levels using real-time PCR. Biol. Proc. Online 8, 1-10.

Gordon, J.W., Scangos, G.A., Plotkin, D.J., Barbosa, J.A. \& Ruddle, F.H. (1980). Genetic transformation of mouse embryos by microinjection of purified DNA. Proc. Natl. Acad. Sci. USA 77, 7380-4.

Gupta, B., Levchenko, T.S. \& Torchilin, V.P. (2005). Intracellular delivery of large molecules and small particles by cellpenetrating proteins and peptides. Adv. Drug Deliv. Rev. $57,637-51$.

Gupta, S.K., Bhandari, B., Shrestha, A., Biswal, B.K., Palaniappan, C., Malhotra, S.S. \& Gupta, N. (2012). Mammalian zona pellucida glycoproteins: structure and 
function during fertilization. Cell Tissue Res. 349, 66578.

Hammer, R.E., Pursel, V.G., Rexroad, Jr C.E., Wall, R.J., Bolt, D.J., Ebert, K.M., Palmiter, R.D. \& Brinster, R.L. (1985). Production of transgenic rabbits, sheep and pigs by microinjection. Nature 315, 680-3.

Hayashi, M.A., Nascimento, F.D., Kerkis, A., Oliveira, V., Oliveira, E.B., Pereira, A., Rádis-Baptista, G., Nader, H.B., Yamane, T., Kerkis, I. \& Tersariol, I.L. (2008). Cytotoxic effects of crotamine are mediated through lysosomal membrane permeabilization. Toxicon 52, 508-17.

Holm, P., Booth, P.J., Schmidt, M.H., Greve, T. \& Callesen, H. (1999). High bovine blastocyst development in a static in vitro production system using SOFaa medium supplemented with sodium citrate and myo-inositol with or without serum-proteins. Theriogenology 52, 683700.

Houdebine, L.M. (2007). Transgenic animal models in biomedical research. Methods Mol. Biol. 360, 163-202.

Kerkis, A., Kerkis, I., Rádis-Baptista, G., Oliveira, E.B., Vianna-Morgante, A.M., Pereira, L.V. \& Yamane, T. (2004). Crotamine is a novel cell-penetrating protein from the venom of rattlesnake Crotalus durissus terrificus. FASEB J. 18, 1407-9.

Kues, W.A. \& Niemann, H. (2011). Advances in farm animal transgenesis. Prev. Vet. Med. 102, 146-56.

Kuzmany, A., Havlicek, V., Wrenzycki, C., Wilkening, S., Brem, G. \& Besenfelder, U. (2011). Expression of mRNA, before and after freezing, in bovine blastocysts cultured under different conditions. Theriogenology 75, 482-94.

Livak, K.J. \& Schmittgen, T.D. (2001). Analysis of relative gene expression data using real-time quantitative PCR and the $2^{-\Delta \Delta C}$ T method. Methods 25, 402-8.

Nascimento, F.D., Hayashi, M.A., Kerkis, A., Oliveira, V., Oliveira, E.B., Rádis-Baptista, G., Nader, H.B., Yamane, T., Tersariol, I.L.S. \& Kerkis, I. (2007). Crotamine mediates gene delivery into cells through the binding to heparan sulfate proteoglycans. J. Biol. Chem. 282, 21349-60.

Nascimento, F.D., Sancey, L., Pereira, A., Rome, C., Oliveira, V., Oliveira, E.B., Nader, H.B., Yamane, T., Kerkis, I., Tersariol, I.L.S., Coll, J. \& Hayashi, M.A.F. (2012). The natural cell-penetrating peptide crotamine targets tumor tissue in vivo and triggers a lethal calcium-dependent pathway in cultured cells. Mol. Pharmaceutics 9, 21121.

Palmiter, R.D., Brinster, R.L., Hammer, R.E., Trumbauer, M.E., Rosenfeld, M.G., Birnberg, N.C. \& Evans, R.M. (1982). Dramatic growth of mice that develop from eggs microinjected with metallothionein-growth hormone fusion genes. Nature 300, 611-5.

Purcell, S.H. \& Moley, K.H. (2009). Glucose transporters in gametes and preimplantation embryos. Trends Endocrinol. Metab. 20, 483-9.

Pursel, V.G., Wall, R.J., Rexroad, Jr C.E., Hammer, R.E. \& Brinster, R.L. (1985). A rapid whole-mounted staining products for nuclei of mammalian eggs. Theriogenology 24, 687-91.

Rádis-Baptista, G. \& Kerkis, I. (2011). Crotamine, a small basic polypeptide myotoxin from rattlesnake venom with cell-penetrating properties. Curr. Pharm. Des. 17, 4351-61.

Rádis-Baptista, G., de la Torre, B.G. \& Andreu, D. (2008). A novel cell-penetrating peptide sequence derived by structural minimization of a snake toxin exhibits preferential nucleolar localization. J. Med. Chem. 51, 70414.

Richard, J.P., Melikov, K., Vives, E., Ramos, C., Verbeure, B., Gait, M.J., Chernomordik, L.V. \& Lebleu, B. (2003). Cellpenetrating peptides: a reevaluation of the mechanism of cellular uptake. J. Biol. Chem. 278, 585-90.

Rideout, W.M., Eggan, K. \& Jaenisch, R. (2001). Nuclear cloning and epigenetic reprogramming of the genome. Science 293, 1093-8.

Rizos, D., Clemente, M., Bermejo-Alvarez, P., Fuente, J., Lonergan, P. \& Gutiérrez-Adán, A. (2008). Consequences of in vitro culture conditions on embryo development and quality. Reprod. Dom. Anim. 43, 44-50.

Rodrigues, M., Santos, A., Torre, B.G., Rádis-Baptista, G., Andreu, D. \& Santos, N.C. (2012). Molecular characterization of the interaction of crotamine-derived nucleolar targeting peptides with lipid membranes. Biochim. Biophys. Acta 1818, 2707-17.

Schwarze, S.R. \& Dowdy, S.F. (2000). In vivo protein transduction: intracellular delivery of biologically active proteins, compounds and DNA. Trends Pharmacol. Sci. 21, $45-8$.

Tervit, H., Whittingham, D. \& Rowson, L. (1972). Successful culture in vitro of sheep and cattle ova. J. Reprod. Fertil. 30, 493-7.

Vandesompele, J., Preter, D.K., Pattynm, F., Poppe, B., Roy, N.V., Paepe, A.D. \& Speleman, F. (2002). Accurate normalization of real-time quantitative RT-PCR data by geometric averaging of multiple internal control genes. Gen. Biol. 3, 1-12.

Watson, A.J., Westhusin, M.E., De Sousa, P.A., Betts, D.H. \& Barcroft, L.C. (1999). Gene expression regulating blastocyst formation. Theriogenology 51, 117-33. 